\title{
$\omega$-conotoxin MVIIA intralesional injection in spinal cord injury in rats
}

\author{
Aplicação intralesional da $\omega$-conotoxina MVIIA no trauma medular em ratos
}

\author{
Karen Maciel de Oliveira ${ }^{\mathrm{I}}$ Nancy Scardua Binda ${ }^{\mathrm{I}}$ Mário Sérgio Lima Lavor ${ }^{\mathrm{II}}$ \\ Carla Maria Osório Silva ${ }^{I}$ Isabel Rodrigues RosadoI \\ Tatiana Malagoli Taguchi ${ }^{I}$ Endrigo Gabellini Leonel Alves ${ }^{\mathrm{I}}$ \\ Marília Martins Melo ${ }^{\mathrm{I}}$ Marcus Vinícius Gomez ${ }^{\mathrm{I}}$ Eliane Gonçalves de Melo ${ }^{\mathrm{I}}$
}

\begin{abstract}
This study aimed to investigate the neuroprotective effect of $\omega$-conotoxin MVIIA (MVIIA) intralesional application in rats submitted to spinal cord injury. Male Wistar rats, weighing $300 g \pm 23.4$, were distributed in five groups: negative control

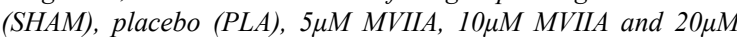
MVIIA MVIIA. After laminectomy of the $12^{\text {th }}$ thoracic vertebra

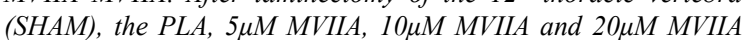
groups were subjected to acute compressive spinal cord trauma for five minutes, and then five minutes later, the animals received specific treatment in a standard total volume of $2 \mu L$, by intralesional route, using sterile PBS as placebo. Locomotor activity was assayed using Basso Beattie Bresnahan (BBB) scale to show the patterning of SCI. With 48 hours of injury, the animals were euthanized, the liquor sample was collected in atlantooccipital space, and also the spinal segment, including the epicenter and caudal region to injury. Assays were performed for mitochondrial viability, serum glutamate, production of reactive oxygen species (ROS) and lipid peroxidation (LP) were performed. The study design was randomized and the data submitted to ANOVA and comparison of means by SNK test, and data from BBB scale were evaluated using Kruskal-Wallis test $(P<0.05)$. There was no significant difference between groups in BBB scores. The MVIIA did not promote decrease in the levels of glutamate, ROS, LP, and did not preserve the mitochondria in the intralesional application five minutes after spinal cord injury in rats.
\end{abstract}

Key words: MVIIA, cone snail, cell viability, glutamate, reactive oxygen species, lipid peroxidation.

RESUMO

Objetivou-se investigar o efeito neuroprotetor da aplicação intralesional da MVIIA em ratos submetidos ao trauma medular. Foram utilizados ratos Wistar, machos, com peso entre $300 \mathrm{~g} \pm 23.4$, distribuidos em cinco grupos: controle

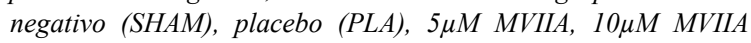

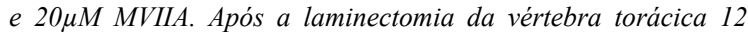

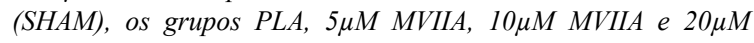
MVIIA foram submetidos ao trauma medular agudo compressivo por cinco minutos e, cinco minutos após o trauma, receberam o tratamento especifico em volume total padrão de $2 \mu L$, pela via intralesional, sendo utilizado como placebo o PBS estéril. A atividade locomotora foi avaliada pela escala proposta por Basso Beattie Bresnahan (BBB), com intuito de mostrar a padronização do trauma medular. Com 48 horas do trauma, os animais foram submetidos à eutanásia, coletou-se amostra do líquor no espaço atlantooccipital e um segmento medular, incluindo o epicentro $e$ região caudal à lesão. Foram realizados ensaios de viabilidade mitocondrial, dosagem de glutamato, produção de espécies reativas de oxigênio (ERO) e peroxidação lipídica (PL). $O$ delineamento do estudo foi inteiramente casualizado e os dados submetidos ao ANOVA, com comparação de médias pelo teste de SNK e os dados do teste BBB foram comparados utilizando o teste Kruskal-Wallis $(P<0.05)$. Em relação aos escores do $B B B$, não houve diferença entre os grupos. A MVIIA não promoveu a diminuição dos níveis do glutamato, ERO, PL e não preservou a mitocôndria na aplicação intralesional, cinco minutos após o trauma medular em ratos.

Palavras-chave: MVIIA, caramujo marinho, viabilidade celular, glutamato, espécies reativas de oxigênio, peroxidação lipídica.

\section{INTRODUCTION}

Among the many events that contribute to secondary neuronal death following spinal cord

IUniversidade Federal de Minas Gerais (UFMG), Belo Horizonte, MG, Brasil. E-mail: kamoliveira@yahoo.com.br. Corresponding author.

"Universidade Estadual de Santa Cruz (UESC), Ilhéus, BA, Brasil. 
injury (SCI), contrasts excitotoxicity mediated by glutamate, excessive accumulation of intracellular calcium with consequent mitochondrial dysfunction and production of reactive oxygen species (ROS). ROS, in turn, react with cellular components, including the lipid plasma membrane, resulting in lipid peroxidation (LP) that leads to membrane rupture and neuronal death (DASURI et al., 2013). Success of SCI treatment depends on how efficiently the secondary injury mechanisms can be altered. So, in an attempt to stop or reduce theses injuries, neuroprotective pharmacological strategies have been developed, however they did not show adequate efficiency.

Spinal cord has several voltage-dependent calcium channels (VDCC), with the $\mathrm{N}$ and $\mathrm{P} / \mathrm{Q}$ type involved in the spinal trauma mechanism, and the $\mathrm{N}$ type expressed in high concentrations in the dorsal laminae gray matter (GOHIL et al., 1994). Thus, calcium channels blockers have been shown great potential in reducing brain and spinal cord injuries by preventing the intense ion influx and thus the lesion progression. Toxins from cone snails such as $\omega$-conotoxin MVIIA or Ziconotide, initially purified as SNX-111, is a potent reversible blocker of $\mathrm{N}$ type calcium channels (OLIVERA et al., 1985), capable to inhibit, in synaptosomes, neurotransmitters release such as norepinephrine (BOWERSOX et al., 1995) and glutamate (GONÇAVES et al., 2011), essential in the development of secondary spinal injury. This drug was approved by the Food and Drug Administration in the United States, for analgesic therapeutic use to treat severe chronic and neuropathic cancer pain (SOUZA et al., 2008; BINGHAM et al., 2010).

The MVIIA application has shown significant improvement in traumatic brain injury in rats (VERWEIJ et al., 2000), cerebral ischemia models (VALENTINO et al., 1993; BOWERSOX et al., 1997) and spinal cord ischemia in rats (BURNS et al., 1999). There are no reports in the literature on research in spinal cord injury and MVIIA. Thus, the aim of this study was to evaluate the neuroprotective effects of MVIIA intralesional injection in different doses following SCI.

\section{MATERIAL AND METHODS}

Twenty-five adult, male Wistar rats, weighting $300 \mathrm{~g} \pm 23.4$, were randomly distributed into five groups. Rats were housed in a controlled environment and provided with commercial rodent food and water ad libitum. This study was carried out in strict accordance with the recommendations in the
Guide for the Care and Use of Laboratory Animals of the National Institute of Health.

Animals were premedicated with morphine sulfate ( $2.5 \mathrm{mg} \mathrm{kg}^{-1}$, subcutaneously), and anesthesia was induced and maintained with isoflurane in a non-rebreathing circuit, through a facemask. The animals were positioned in a stereotactic apparatus, received prophylactic antibiotic with cephalotin (60mg $\mathrm{kg}^{-1}$, subcutaneously) and then, prepared for asseptic surgery. An incision was made in the dorsal midline skin and subcutaneous tissue extending from $\mathrm{T} 8$ to $\mathrm{L} 1$, and the muscle and tissue overlying the spinal column was blunt dissected away revealing the laminae. Using the spiny process of T13 as a landmark, laminectomy of T12 was performed with a pneumatic drill and the lamina was carefully removed to expose the spinal cord. Extradural compression of the spinal cord at the vertebral level of T12 was achieved as previously described (TORRES et al., 2010; OLIVEIRA et al., 2014) for five minutes, using a weigh of $40.5 \mathrm{~g} \mathrm{~cm}^{-1}$. Five minutes later, an intralesional injection was performed according to the experimental group. The incision was closed in two layers. The animals received saline solution ( $15 \mathrm{ml} \mathrm{kg}^{-1}$, subcutaneously) and were allowed to recover from anesthesia in a warmed $\left(37^{\circ} \mathrm{C}\right)$ box with oxygen therapy.

Post-operative care procedures involved morphine sulfate $\left(2.5 \mathrm{mg} \mathrm{kg}^{-1}\right.$, orally, every 4 hours) at the surgery day and tramadol chloride $\left(5 \mathrm{mg} \mathrm{kg}^{-1}\right.$, subcutaneously, every 8 hours) for two days, and cephalexin (60mg kg-1, orally, twice daily) and manual expression of the bladder (three times a day) until euthanasia.

The animals were randomly distributed into five groups, with five rats each, according to the treatment protocol: sham-operated (SHAM), placebo (PLA - sterile PBS), $5 \mu \mathrm{M}$ MVIIA, $10 \mu \mathrm{M}$ MVIIA e $20 \mu \mathrm{M}$ MVIIA. MVIIA was prepared in sterile PBS diluting respectively 10, 20 and $40 \mathrm{pmol}$ in a PBS volume of $2 \mu \mathrm{L}$ to reach these final concentrations. In SHAM, the procedure performed was laminectomy. The other groups, five minutes after the trauma, received the specific treatment at the lesion epicenter (intralesional route). This treatment was delivered using $10 \mu \mathrm{L}$ Hamilton syringe attached to a polyethylene tube (PE10) and

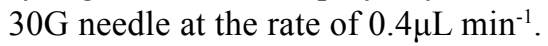

Side effects evaluation started one day before the surgical procedure for animals conditioning, in the first five hours after application of the toxin and daily until the day of euthanasia. Rats were placed in the open field and evaluated for 
15 minutes to the presence of generalized and tail tremor, ranking as absent, mild, moderate and severe.

Beginning three days prior to SCI, animals were allowed to adapt to the open field arena for behavioral testing. Rats were exposed to the open field prior to the surgery and after trauma. During this evaluation, the animals were filmed for four minutes and the videos were later analyzed by two observers who were blinded to animal groups, assigning a score that ranged from zero to 21, using the Basso Beattie Bresnahan (BBB) locomotor rating scale (BASSO et al., 1996) showing the pattern of SCI.

On 48 hours after surgery, the rats were premedicated with xylazine $\left(8 \mathrm{mg} \mathrm{kg}^{-1}\right.$, intraperitoneally) and deeply anesthetized with an overdose of sodium thiopental (100mg kg-1, intraperitoneally). Next, the liquor sample $(50-80 \mu \mathrm{L})$ was collected in atlantooccipital space. Glutamate measurement in liquor was performed enzymatically after the increase in the fluorescence due to the production of $\mathrm{NADPH}+$ in the presence of glutamate dehydrogenase and NADP + . For the assay, was added $1.8 \mathrm{ml}$ incubation solution $\mathrm{KRH}$ (Krebs Ringer HEPES) without calcium $(124 \mathrm{~mm} \mathrm{NaCl}, 4 \mathrm{mM} \mathrm{KCl}, 1.2 \mathrm{~mm}$ $\mathrm{MgSO}_{4}, 10 \mathrm{mM}$ HEPES $), 5 \mu \mathrm{L}$ of NADP $(1 \mathrm{mM}), 22 \mu \mathrm{L}$ of glutamate dehydrogenase, $5 \mu \mathrm{L}$ of sample and $5 \mu \mathrm{L}$ of standard glutamate. The excitation wavelength was set at $360 \mathrm{~nm}$ and the emission wavelength to $450 \mathrm{~nm}$ using a spectrofluorimeter (Shimadzu RF-5301PC, Japan). Glutamate level was calculated as pmol of glutamate per milligram of protein.

Mitochondrial viability was determined by converting 2,3,5-Triphenyltetrazolium (TTC) to the insoluble formazan. The reduction of this compound is dependent on mitochondrial respiratory activity. Therefore, this conversion can be proportional to the number of viable cells. After euthanasia, spinal cord fragment collected from lesion epicenter was subjected to $400 \mathrm{mM}$ with the aid of a tissue cutter and after processing in the perfusion chamber, the slices were incubated at $37^{\circ} \mathrm{C}$ in a solution of $2 \%$ TTC for 90 minutes. After this period, the TTC was removed and the tissue washed with $0.9 \%$ saline solution and then added $1.5 \mathrm{~mL}$ of a solution containing dimethylsulfoxide (DMSO) and ethanol in a 1:1 ratio and incubated for 48 hours, at room temperature and protected from light, to solubilize the formazan. The reading was held in a spectrophotometer at $485 \mathrm{~nm}$ and the results normalized by tissue weight.

Spinal cord fragment was collected from lesion epicenter and dichlorofluoresceindiacetate (DCF-DA) levels were determined as an indicator of the peroxide production of cell components. Fragment was immediately cooled to $-20^{\circ} \mathrm{C}$ in TRIS- $\mathrm{HCl}$ buffer solution (10mM, pH7.4). After homogenization, it was subjected to centrifugation $\left(10000 \mathrm{rpm}, 5^{\circ} \mathrm{C}\right.$, $10 \mathrm{~min}$ ) and an aliquot of $20 \mu \mathrm{L}$ of this supernatant was added to $80 \mu \mathrm{L}$ DCF-DA $125 \mu \mathrm{M}$. The plate was incubated in triplicate in the dark for $1 \mathrm{~h}$ at $37^{\circ} \mathrm{C}$ until the measurement of the fluorescence $(488 / 525 \mathrm{~nm})$ in Victor X4 apparatus (Perkin-Elmer). Results were normalized by protein content.

Lipid peroxidation was determined by quantifying the content of malondialdehyde (MDA) present in the homogenate supernatant, also in caudal segment, through the colorimetric reaction with thiobarbituric acid (TBA) at high temperatures. After storage at $-20^{\circ} \mathrm{C}$, the sample was homogenized in sonicator (Branson Sonifier Model 250) (3 cycles of $4 \mathrm{~s}$ each) and the homogenate centrifuged at 2500rpm, $4^{\circ} \mathrm{C}$ for $10 \mathrm{~min}$. Pipetted initially $134 \mu \mathrm{L}$ of $0.8 \%$ TBA, $134 \mu \mathrm{L}$ of acetic acid buffer $(125 \mathrm{ml} \mathrm{H} 0 ; 18,84 \mathrm{ml}$ of glacial acetic acid; 5,63ml 12N HCl PA; $\mathrm{pH} 3,4)$ and $54 \mu \mathrm{L}$ of $\mathrm{H}_{2} 0$. Upon incubation, $54 \mu \mathrm{L}$ of sample and $54 \mu \mathrm{L}$ of $8.1 \%$ SDS (sodium dodecyl sulphate) was added, leaving for 90 minutes at $95^{\circ} \mathrm{C}$. The MDA content was measured at a wavelength of $532 \mathrm{~nm}$ and the results normalized by protein content.

The determination of protein was done by the colorimetric method described by BRADFORD (1976). A volume of $2 \mu \mathrm{L}$ of supernatant, obtained suspending the pellet from caudal segment of the spinal cord, was used for quantification. Samples in triplicate were placed in plates by adding $500 \mu \mathrm{L}$ of $0.15 \mathrm{M}$ of $\mathrm{NaCl}$ and $500 \mu \mathrm{L}$ of Bradford reagent in each sample. The mixture was incubated for 5 minutes, stirring, and then proceeded to read the absorbance in a spectrophotometer at a wavelength of $595 \mathrm{~nm}$. The protein concentration was calculated using a standard curve dilution of $1 \mathrm{mg} \mathrm{BSA} \mathrm{ml}^{-1}$ with $1,3,5,7$ and $10 \mathrm{mg}$.

All data collected were analyzed using Prism 5 for Windows (GraphPad Software. La Jolla, CA, USA). Data from BBB locomotor rating scale were evaluated using Kruskal-Wallis test. Other data were submitted to analyses of variance, and means were compared using Student-Newman-Keuls test. For all analyses, $\mathrm{P}$ value $<0.05$ was considered statistically significant.

\section{RESULTS AND DISCUSSION}

The model of experimental acute spinal cord injury allowed the reproduction of a moderate to severe trauma, easy, inexpensive and standardized. Before surgery, all animals showed clinical neurological parameters within the normal 
range, which was represented by score 21 on the scale of BASSO et al. (1996). Twenty-four hours after surgery, there was no difference between groups subjected to trauma treated with IL route (PLA, $4 \pm 4.5,5 \mu \mathrm{M}, 2 \pm 4.2 ; 10 \mu \mathrm{M}, 3 \pm 4.2 ; 20 \mu \mathrm{M}, 7,6 \pm 3.58$ ) (Figure 1A), which showed standardized SCI.

Due to MVIIA peptidic nature, the cone snail toxins are not orally available and they must be delivered directly into the central nervous system (CNS) (SNUTCH, 2005). Thus, IL route was chosen by allowing the exact site of treatment. Although it is not the most feasible clinically, is an easy, and safe method.
This is the first study that evaluates the neuroprotective effects of $\omega$-conotoxin MVIIA in vivo in rats subjected to SCI. In this experiment, MVIIA concentrations were chosen from 5 to $20 \mu \mathrm{M}$ of MVIIA due to the variability of doses reported in the literature, mostly antinociceptive studies where concentrations of 3 to $200 \mu \mathrm{M}$ showed efficacy in blocking the N-type VDCC (SOUZA et al., 2008; HAMA \& SAGEN, 2009; SOUZA et al., 2011; SOUZA et al., 2013), with side effects as a limiting factor. In agreement with HAMA \&SAGEN (2009), the lowest dose $(5 \mu \mathrm{M})$ had no complications. But

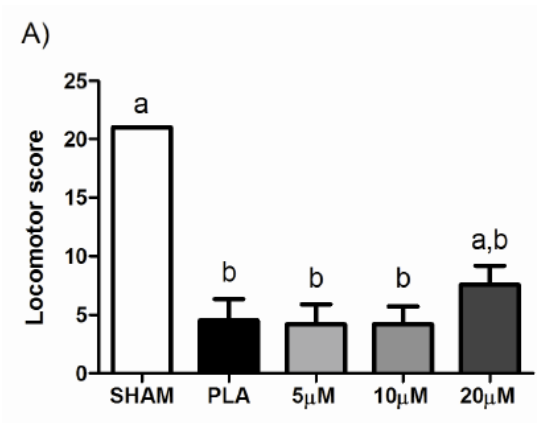

C)

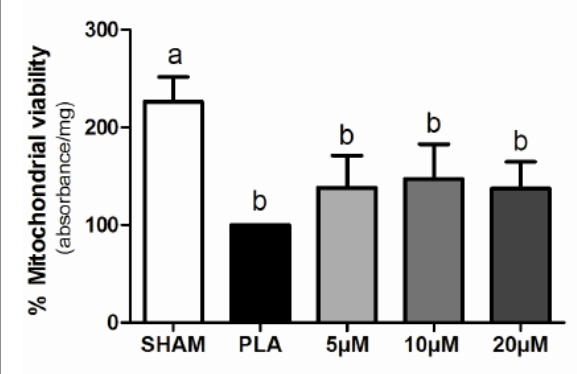

E)

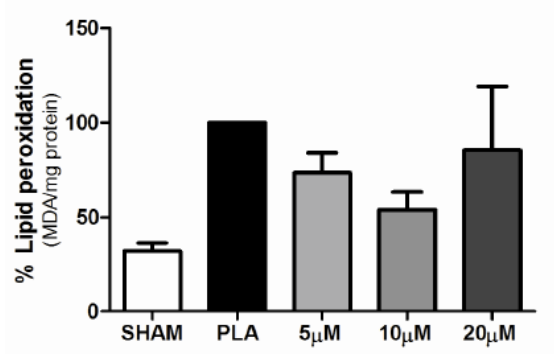

B)

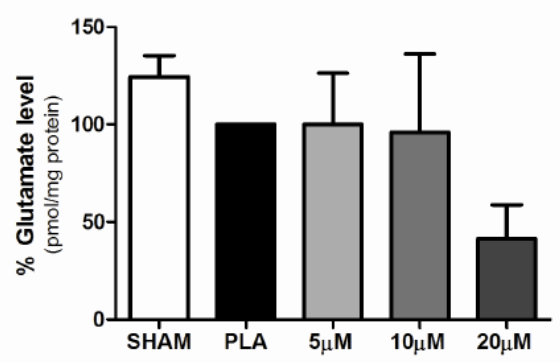

D)

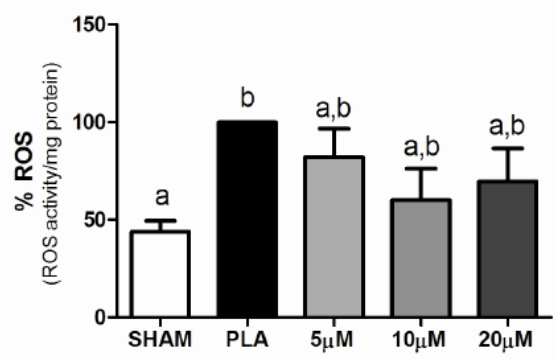

Figure 1- Median ( \pm mean standard deviation) of BBB scores $(\mathrm{A})$ and mean number ( \pm mean standard deviation) of glutamate levels (B), mitochondrial viability (C), production of reactive oxygen species (ROS) (D) and lipid peroxidation (E) of rats subjected to dorsal laminectomy (SHAM) and spinal cord injury and treated via intralesional with different doses of MVIIA $(5 \mu \mathrm{M}, 10 \mu \mathrm{M}$ and $20 \mu \mathrm{M})$ or PBS as a positive control (PLA). Lowercase letters express statistically differences among groups $(\mathrm{P}<0.05)$. 
higher concentrations showed dose-dependent side effects as tremor of the body and tail graded in moderate and severe with doses respectively of 10 $(80 \%, 4 / 5)$ and $20 \mu \mathrm{M}(100 \%, 5 / 5)$.

The time of application of five minutes after the SCI was chosen in order to early block the $\mathrm{N}$-type VDCC and decrease injuries resulting from exaggerated influx of calcium and its deleterious effects (DASURI et al., 2013). In view of the toxin rapid onset action, approximately 22 minutes (BOWERSOX \& LUTHER, 1994), it was believed that this moment would inhibit the first increase of calcium in the $45^{\text {th }}$ minute and his subsequent elevation (HAPPEL et al., 1981). Moreover, this time was essential to use the IL route, taking advantage of the same surgical procedure of SCI, which avoided another surgery on the same day, greater tissue trauma, inflammation and animal stress. Besides that, as it is the first research with MVIIA in SCI, and the present research initially decided to study the possible beneficial effects of the conotoxin in early application to subsequently permit future evaluation of the therapeutic window and its clinical feasibility.

In this MVIIA application model, the glutamate concentrations in cerebrospinal fluid did not differ 48 hours after SCI, reaching the level of the negative control (SHAM), possibly by the time of evaluation since it is reported normal levels of glutamate in three hours after SCI. Mean ( \pm standard deviation) concentration of glutamate in the cerebrospinal fluid compared to placebo (100) were $124.14 \% \pm 22.46 \quad$ (SHAM), $100.1 \% \pm 58.21$ (5 $\mu \mathrm{M}$ MVIIA), $95.92 \% \pm 89.75(10 \mu \mathrm{M}$ MVIIA) and

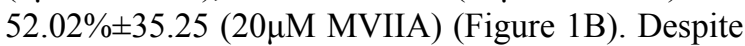
the observation of MVIIA in reducing glutamate at early times (SOUZA et al., 2008; GONÇAVES et al., 2011), some authors pointed out that this fact is not the only implicated in toxin neuroprotection (VALENTINO et al., 1993), since high doses are required for regulation of glutamate release in less than $50 \%$ when compared to effective inhibitors levels (BOWERSOX et al., unpublished data, 1999 cited by WANG \& BOWERSOX, 2000).

Regarding mitochondrial viability, the MVIIA concentrations did not show cell preservation and the trauma groups were significantly lower when compared to SHAM $(226.33 \% \pm 61.89)$. The test results were $151.69 \% \pm 80.75$ ( $5 \mu \mathrm{M}$ MVIIA), $161.5 \% \pm 87.26$ $(10 \mu \mathrm{M}$ MVIIA) and $150.77 \% \pm 67.58(20 \mu \mathrm{M}$ MVIIA) (Figure 1C). Interestingly VALENTINO et al. (1993), in cerebral ischemia model, and VERWEIJ et al. (2000), in traumatic brain injury, observed that MVIIA injected 15 minutes before or within one hour after the injury did not preserve the mitochondria as applied late with four or six hours after cerebral ischemia (VALENTINO et al., 1993;VERWEIJ et al., 2000). Then, VERWEIJ et al. (2000) suggested that MVIIA would be more efficient during critical periods of calcium.

When comparing the groups treated with MVIIA in $5 \mu \mathrm{M}(82.17 \% \pm 32.44), \quad 10 \mu \mathrm{M}$ $(60.05 \% \pm 36.08)$ and $20 \mu \mathrm{M} \quad(69.85 \% \pm 37.27)$ concentrations, it was noted that no dose was capable of reducing ROS production in relation to the PLA (100) (Figure 1D). As the mitochondria releases activators of the apoptosis cascade and further enhances the secondary injuries to SCI, as oxidative damage, and ROS production (PATEL et al., 2010), MVIIA did not reduce ROS possibly due to not preserving the mitochondria, in agreement with previous results, or not decreased the calcium entrance.

It is also known that, among these ROS, decomposition of peroxynitrite form highly cytotoxic free radicals leading to PL (DASURI et al., 2013). In this study, MVIIA applied with five minutes was also not effective in reducing the PL after SCI, differing from the SHAM $(32.17 \% \pm 10.84)$ and PLA (100) $(\mathrm{P}<0.05)$. The MDAmean ( \pm standard deviation $)$ were: $73.51 \% \pm 23.62, \quad 54.09 \% \pm 20.97$ and $85.48 \% \pm 75.31$ to $5 \mu \mathrm{M}, 10 \mu \mathrm{M}$ and $20 \mu \mathrm{M}$ MVIIA when compared to PLA (100) (Figure 1E). The attenuation of ROS production is directly related to the decrease in the PL (DASURI et al., 2013). However, this was not seen with MVIIA treatment, probably because the inhibition of ROS was not enough to reduce PL.

Based on our results, when MVIIA applied early to SCI did not preserve a major source of free radicals, mitochondria, was unable to reduce the production of ROS and their secondary reaction, lipid peroxidation, and did not promote decrease in the levels of glutamate. In this study, MVIIA possibly did not reduce significantly the intracellular calcium entry, enabling large formation of oxidative damages with consequent loss of mitochondrial viability and lack of neuroprotective effects.

\section{CONCLUSION}

The results demonstrate that early administration of MVIIA via IL route did not promote the reduction of the secondary events to SCI in rats.

\section{ACKNOWLEDGMENTS}

The authors gratefully acknowledge the support from Conselho Nacional de Desenvolvimento Científico e Tecnológico (CNPq) for supporting the project and for granting a scholarship. 


\section{BIOETHICS AND BIOSSECURITY COMMITTEE APPROVAL}

Project approved under protocol 226/2012.

\section{REFERENCE}

BASSO, M. et al. Graded histological and locomotor outcomes after spinal cord contusion the NYU weight-drop device versus transection. Experimental Neurology, v.139, p.244-256, 1996. Available from: <http://www.sciencedirect.com/science/article/ pii/S001448 8696900989>. Accessed: Jun. 30, 2011. doi: 10.1006/ exnr.1996.0098.

BINGHAM, J.P. et al. Drugs from slugs - Past, present and future perspectives of $\omega$-conotoxin research. Chemico-Biological Interactions, v.183, p.1-18, 2010. Available from: <http://www. sciencedirect.com/science/article/pii/S0009279709004244>. Accessed: Jun. 12, 2012. doi: 10.1016/j.cbi.2009.09.021.

BOWERSOX, S.S.; LUTHER R. Pharmacotherapeutic potential of omega-conotoxin MVIIA (SNX-111), an N-type neuronal calcium channel blocker found in venom of Conus magus. Toxicon, v.36, p.1651-1658, 1998. Available from: <http://www.sciencedirect. com/ science/article/pii/S0041010198001585>. Accessed: Jan. 15, 2013. doi: 10.1016/S0041-0101(98)00158-5.

BOWERSOX, S.S. et al. Differential blockade of voltage-sensitive calcium channels at the mouse neuromuscular junction by novel -conopeptides and -agatoxin- IVA. Journal of Pharmacology and Experimental Therapeutics, v.273, p.248-256, 1995. Available from: $<$ http://jpet.aspetjournals.org/content/273/1/248.long $>$. Accessed: Jan 20, 2013. PMID: 7714772 .

BOWERSOX, S.S. et al. Selective blockade of N-type voltagesensitive calcium channels protects against brain injury after transient focal cerebral ischemia in rats. Brain Research, v.747, p.343-347, 1997. Available from: <http://www.sciencedirect.com/ science/article/pii/ S000689939601325X $>$. Accessed: Jul. 15, 2013. doi: 10.1016/S0006-8993(96)01325-X.

BRADFORD, M. A rapid and sensitive method for the quantitation of microgram quantities of protein utilizing the principle of proteindye binding. Analytical Biochemistry, v.72, p.248-254, 1976. Available from: $<$ http://www.sciencedirect.com/science/article/pii/ 0003269776905273 >. Accessed: Jul. 20, 2013. doi: 10.1016/00032697(76)90527-3.

BURNS, L.H. et al. The neuroprotective effects of intrathecal administration of the selective N-type calcium channel blocker ziconotide in a rat model of spinal ischemia. Journal of Vascular Surgery, v.30, p.334-343, 1999. Available from: <http://ac.elscdn.com/S074152149970145X/1-s2.0-S074152149970145Xmain.pdf? tid=4dc08f60-2321-11e4-a7d0-00000aab0f6b\&acdnat $=14079588479 \mathrm{~d} 76165 \mathrm{~b} 7857 \mathrm{f} 210 \mathrm{c} 552 \mathrm{da} 7 \mathrm{abe} 5 \mathrm{f} 7 \mathrm{~b} 05>$. Accessed: Sept. 04, 2013. doi: 10.1016/S0741-5214(99)70145-X.

DASURI, K. et al. Oxidative stress, neurodegeneration, and the balance of protein degradation and protein synthesis. Free Radical Biology and Medicine, v.62, p.170-185, 2013. Available from: $<$ http:// www.sciencedirect.com/science/article/pii/S0891584912011410>. Accessed: Nov. 05, 2013. doi: 10.1016/j.freeradbiomed.2012.09.016.

GOHIL, K. et al. Neuroanatomical distribution of receptors for a novel voltage-sensitive calcium channel antagonist, SNX-
230 (conopeptide MVIIC). Brain Research, v.653, p.258-266, 1994. Available from: <http://www.sciencedirect.com/science/ article/pii/ 0006899394903980>. Accessed: Nov. 15, 2013. doi: 10.1016/0006-8993(94)90398-0.

GONÇAVES, J.M et al. The effect of spider toxin PhTx3-4, $\omega$-conotoxins MVIIA and MVIIC on glutamate uptake and on capsaicin-induced glutamate release and $[\mathrm{Ca} 2+] \mathrm{i}$ in spinal cord synaptosomes. Cellular and Molecular Neurobiology, v.31, p.277-283, 2011. Available from: $<$ http://link.springer.com/article /10.1007\%2Fs10571-010-9618-5>. Accessed: Jun. 21, 2012. doi: $10.1007 / \mathrm{s} 10571-010-9618-5$

HAMA, A.; SAGEN, J. Antinociceptive effects of the marine snail peptides conantokin-G and conotoxin MVIIA alone and in combination in rat models of pain. Neuropharmacology, v.56, p.556-563, 2009. Available from: <http://www.ncbi.nlm.nih.gov/ pmc/articles/ PMC2735251/pdf/nihms98070.pdf>. Accessed: Ago. 06, 2013. doi: 10.1016/j.neuropharm.2008.10.008.

HAPPEL, R.D. et al. Ca2 ${ }^{+}$accumulation in experimental spinal cord trauma. Brain Research, v.211,p.476-479, 1981. Available from: $<\mathrm{http} / /$ www.sciencedirect.com/science/article/pii/0006899381909768>. Accessed: Ago. 09, 2013. doi: 10.1016/0006-8993(81)90976-8.

OLIVEIRA, K.M. et al. Omega-conotoxin MVIIC attenuates neuronal apoptosis in vitro and improves significant recovery after spinal cord injury in vivo in rats. International Jounal of Clinical and Experimental Pathology, v.7, p.3524-3536, 2014. Available from: <http://www.ijcep.com/files/ijcep0000859.pdf>. Accessed: Jul. 23, 2014. PMCID: PMC4128966.

OLIVERA, B.M. et al. Peptide neurotoxins from fish-hunting cone snails. Science, v.230, p.1338-1343, 1985. Available from: <http:// www.sciencemag.org/content/230/4732/1338.long $>$. Accessed: Dec. 19, 2011. doi: 10.1126/science. 4071055 .

PATEL, S.P. et al. Acetyl-L-carnitine ameliorates mitochondrial dysfunction following contusion spinal cord injury. Journal of Neurochemistry, v.114, p.291-301, 2010. Available from: $<$ http://www.ncbi.nlm.nih.gov/pmc/articles/PMC2897952/pdf/ nihms198132.pdf>. Accessed: Ago. 15, 2013. doi: 10.1111/j.14714159.2010.06764.x

SNUTCH, T.P. Targeting chronic and neuropathic pain: The N-type calcium channel comes of age. NeuroRx: The Journal of the American Society for Experimental NeuroTherapeutics, v.2, p.662-670, 2005. Available from: <http://www.ncbi.nlm.nih. gov/pmc/articles/PMC1201323/pdf/neurorx002000662.pdf $>$. Accessed: Jun. 21, 2012. doi: 10.1602/neurorx.2.4.662.

SOUZA, A.H. et al. An evaluation of the antinociceptive effects of Phalb, a neurotoxin from the spider Phoneutrianigriventer, and $\omega$-conotoxin MVIIA, a cone snail Conus magus toxin, in rat model of inflammatory and neuropathic pain. Cellular and Molecular Neurobiology, v.33, p.59-67, 2013. Available from: <http://link. springer.com/article/10.1007\%2Fs10571-012-9871-x>. Accessed: Sept. 04, 2013. doi: 10.1007/s10571-012-9871-x.

SOUZA, A.H. et al. Analgesic effect in rodents of native and recombinant Phalb toxin, a high-voltage-activated calcium channel blocker isolated from armed spider venom. Pain, v.140, p.115-126, 2008. Available from: <http://linkinghub.elsevier.com/ retrieve/pii/S0304-3959(08)00404-1>. Accessed: Ago. 08, 2013. doi: 10.1016/j.pain.2008.07.014.

Ciência Rural, v.46, n.1, jan, 2016. 
SOUZA, A.H. et al. Antiallodynic effect and side effects of Pha1b, a neurotoxin from the spider Phoneutrianigriventer: comparison with $\omega$-conotoxin MVIIA and morphine. Toxicon, v.58, p.626-633, 2011. Available from: <http://linkinghub.elsevier.com/retrieve/ pii/S0304-3959(08)00404-1>. Accessed: Ago. 08, 2013. doi: 10.1016/j.toxicon.2011.09.008.

TORRES, B.B.J. et al. Effects of dantrolene on apoptosis and immunohistochemical expression of NeuN in the spinal cord after traumatic injury in rats. International Journal of Experimental Pathology, v.91, p.530-536, 2010. Available from: <http://www. ncbi.nlm.nih.gov/pmc/articles/PMC3010552/>. Accessed: Feb. 04, 2011. doi: 10.1111/j.1365-2613.2010.00738.x.

VALENTINO, K. et al. A selective N-type calcium channel antagonist protects against neuronal loss after global cerebral ischemia. Proceeding of the National Academy of Sciences of the United States, v.90, p.7894-7897, 1993. Available from: <http://
www.ncbi.nlm.nih.gov/pmc/articles/PMC47249/>. Accessed: Feb. 04, 2011. doi: 10.1073/pnas.90.16.7894.

VERWEIJ, B.H. et al. Improvement in mitochondrial dysfunction as a new surrogate efficiency measure for preclinical trials: doseresponse and time-window profiles for administration of the calcium channel blocker Ziconotide in experimental brain injury. Journal of Neurosurgery, v.93, p.829-834, 2000. Available from: $<$ http://thejns.org/doi/pdf/10.3171/jns.2000.93.5.0829>. Accessed: Sept. 05, 2013. doi: 10.3171/jns.2000.93.5.0829.

WANG, Y.X.; BOWERSOX, S.S. Analgesic properties of ziconotide, a selective blocker of N-type neuronal calcium channels. CNS Drug Reviews, v.6, p.1-20, 2000. Available from: $<$ http://onlinelibrary.wiley.com/doi/10.1111/j.1527-3458.2000. tb00134.x/pdf $>$. Accessed: Ago. 08, 2013. doi: 10.1111/j.15273458.2000.tb00134.x. 